\title{
Important Factors Influencing Consumers Planned Purchase Behavior of SMEs Foodservices Business: Case Study Taichan's Satay
}

\author{
Jono Mintarto Munandar ${ }^{1}$, Bunga Zataisma² \\ ${ }^{1}$ Lecturer in Department of Management, Faculty of Economy and Management, IPB \\ University, +628111104474, jonomu@apps.ipb.ac.id (coresponden author) \\ ${ }^{2}$ Alumnae of Department of Management, Faculty of Economy and Management, IPB \\ University, +6281269253434
}

\begin{abstract}
Taichan's satay is a type of food business (restaurant or street food) selling grilled chicken as the city's mainstay product. This study aims to identify the important factors influencing the purchasing process and identify the factors influencing the planned purchasing behavior of customers of Taichan's satay in the city of Bogor. The non-probability sampling method with accidental sampling technique was carried out for this study. The results showed that purchasing behavior among Taichan's satay consumers in Bogor City is significantly influenced by product-price-personal quality and prestige.
\end{abstract}

Keywords: purchasing behavior, the theory of planned behavior, variance-based SEM, Taichan satay.

\section{Introduction}

Understanding consumer behavior is the core of marketing. A marketer must understand how people make decisions about the purchase and use of a service and what determines their satisfaction after consuming that service [1]. Customer satisfaction is a condition where needs, desires, and expectations can be met through the products consumed [2]. Behavior is very important for marketing strategies because only through behavior the sales and profits are obtained [3].

The behavior of a consumer before making a product purchase is either can have been planned or have not been planned [4]. Everyone has a model of consumer behavior, which is a conception of how this behavior occurs and is formed. If this model is accurate, it can design effective strategies to influence that behavior. However, if it is not accurate, then the opposite can happen [5].

Therefore it is necessary to analyze the factors influencing consumer purchasing decisions according to the behavior of each individual because each individual has a different buying behavior. Especially for a producer who runs 
his business in a type of business that is growing rapidly. Besides, producers must be able to satisfy consumers as well so they can compete to advance their business. Regarding businesses that are growing rapidly, the food and beverage business is currently one of the businesses that are in great demand both by producers and consumers, especially in the culinary field. The emergence of a variety of unique foods, culinary tourism, and culinary trends as a community activity, is a proof that this business is growing rapidly in various regions in Indonesia. One of them is in the city of Bogor, West Java.

Bogor is one of the cities which has a strategic location as a buffer city of the capital and is closed to the Puncak tourist area. The geographical location causes the city of Bogor to develop yearly. Based on Bogor BPS data, there is an increased population in Bogor City every year. Every year, the increased population in Bogor City is an attractive market potential. The development of the population in Bogor city tends to increase. In 2010 the population of the city of Bogor was 958,115 and in 2017 it had increased to 1,081,009 [6]. The population growth was followed by an increase in Bogor City Gross Regional Domestic Product (GRDP) (Figure 1). GRDP is the gross added value of all goods and services that are created or produced in the domestic territory of a country arising from various economic activities in a certain period regardless of whether the production factors are owned by residents or non-residents. The value of GRDP can reflect the picture of the regional economy in general and the level of welfare of its people. The size of GRDP roughly describing the level of community welfare is the value of GRDP per capita [6]. The level of welfare of Bogor City residents despite fluctuations but generally increases every year as shown in Figure 1.

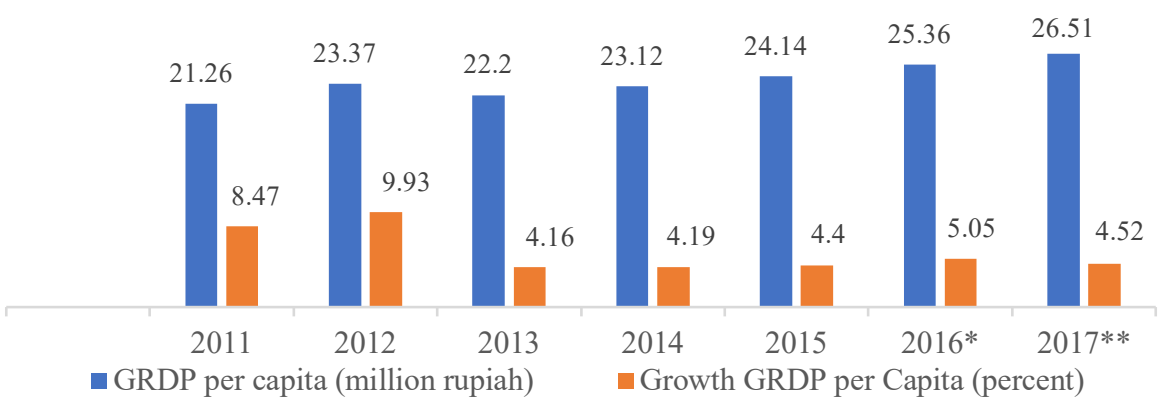

* Preliminary figures

*** Very Preliminary figures

Fig. 1. Bogor City GRDP per capita. Source: Bogor City BPS Data (2018) 
The food and beverage business which is included in the transportation and food and beverage providers sector has experienced growth in the last three years which is contributing to the increase in the Gross Regional Domestic Revenue (PDRB) of Bogor City, including its culinary. On weekends, Bogor City has always been the second favorite place after Bandung for culinary tours with the number of visitors reaching 400 thousand people [7]. Based on Bogor City BPS data, there was an increase in GRDP percentage in Category I, Provision of Accommodation and Food and Beverage, especially in the last three years specifically in 2014 amounted to $5.64 \%$, in 2015 amounted to $5.70 \%$ and the most significant increase was in in 2016 of $8.05 \%$ [8]. Besides, the provision of accommodation and food and beverages is included in the 8 major industries with high-value growth (above 8\%) in 2016, after Information and Communication, Security and Financial Services, Health Services and Social Activities, Corporate Services, Transportation and Warehousing, Other Services, and Real Estate.

According to the increasing population and GRDP growth which is increasing every year, it is known that in 2015 there were $75.49 \%$ of the population of Bogor City spent an average of more than $\mathrm{Rp} \mathrm{500,000} \mathrm{in} \mathrm{a} \mathrm{month}$ to fulfill their basic needs. The largest percentage of the population is the population with a monthly per capita expenditure above Rp 1,000,000 as much as $39.12 \%$ as shown in Figure 2. This shows that the population of Bogor City spent quite a lot of money to fulfill their basic living needs which were used to fulfill their food and drink needs.

\begin{tabular}{l|c|c|c|c|}
\hline & & 409.95 & \\
\hline 256.85 & 202.832 & 178.29 & \\
\hline \\
\hline
\end{tabular}

Fig. 2. Bogor City residents according to the expenditure category in 2015. Source: Bogor City BPS Data (2016)

The city of Bogor with all of its advances has opened up opportunities for the development of various types of businesses. Food and drinks are one of the favorite types of businesses in various regions. Various types of food and beverage businesses are always come up and long-lasting, from small-scale 
businesses to large-scale businesses. Bogor City has various types of food and beverage businesses, both traditional and modern food, large or small, and from simple to unique concepts. One of the businesses being developed in the city of Bogor is Taichan's Satay.

The development of the Taichan's Satay business in Bogor City and the opportunity to advance the business encourage the needs for research to improve the quality of its services by mapping, knowing, and fulfilling what is expected and desired by consumers. It can be seen through the behavior of their consumers towards the purchase of Taichan's Satay. One of the alternative approaches to understand consumer behavior is given by the Theory of Planned Behavior (TPB). This theory was first explained by Icek Ajzen in 1985. TPB does not focus on evaluating usefulness of products or services, but rather on the particular consumer behavior interest [9].

Based on these explanations, this study aims to determine the purchasing decision factors that significantly influence the buying behavior of Taichan's Satay consumers in Bogor City, especially on consumers with planned buying behavior. As for analyzing factors that contribute to consumer purchasing intentions for SME food products, it is done by using a sample of Taichan's Satay.

\section{Literature Review}

\subsection{Theory of Planned Behavior}

Theory of Planned Behavior originates from the Theory of Reasoned Action (TRA) which is used to explain all of a person's behavior when that person can control himself. TRA explains the stages of humans doing something. Initially, behavior was determined by intention. Furthermore, intention can be explained in the form of attitudes toward subjective behavior and norms. The third stage considers subjective attitudes and norms in the form of beliefs about the consequences of doing the behavior and about normative expectations of the relevant reference person. Overall, a person's behavior can be explained by considering his beliefs. Because someone's belief represents the information they get about themselves and their surroundings [10].

TRA was expanded and modified by Ajzen, then it was named Theory of Planned Behavior (TPB) and added a non-existent construct, namely perceived behavioral control. The TPB shows that human action is directed by the following three kinds of beliefs: 1) Behavioral beliefs, namely beliefs about the likelihood of the occurring behaviors. In TRA this is called attitude towards 
the behavior; 2) Normative beliefs, namely beliefs about normative expectations of others and motivation to agree with these expectations. In TRA, these are called subjective norms on behavior; 3) Control beliefs, namely beliefs about the existence of factors that will facilitate or hinder the performance of behavior and the perceived strength of the factors. In TRA, this construct does not exist and is added to TPB, this is as perceived behavioral control.

\subsubsection{Attitude Towards the Behavior}

Attitude is defined as a person's evaluation of the behavior and is based on the expected positive and negative results associated with behavioral beliefs [11]. Attitude is also interpreted as evaluation, emotional feeling, and the tendency to like or dislike someone's actions towards objects or ideas [12]. Behavior is a real action or activity that is carried out [12]. According to Jogiyanto (2008), attitude toward behavior is a comprehensive evaluation of a person in carrying out a behavior [12]. As previously explained, in the TRA, attitude toward behavior is determined by strong beliefs about the behavior which are called behavioral beliefs.

\subsubsection{Subjective Norms on Behavior}

A person's subjective norms represent the perceived social pressure to engage in or avoid certain behaviors, and are based on normative assumptions that are considered important from important references (normative beliefs) [11]. Subjective norms are based on normative beliefs, namely beliefs in certain referents [13]. Meanwhile, according to Jogiyanto (2008), subjective norms are a person's perception or view of the beliefs of others which will influence the intention to do or not do the behavior being considered [10]. Subjective norms which are the second determinant of intention are also assumed to be a function of beliefs, but beliefs of different kinds, namely one's beliefs that certain individuals or groups approve or disagree with carrying out a behavior. If it becomes a point of reference for directing behavior, these individuals or groups are known as referents [10].

\subsubsection{Perceived Behavioral Control}

Perceived behavioral control is an individual's perception of whether easy or not easy to realize a certain behavior [14]. According to Rotter (1990) in Ajzen (2005), perceived behavioral control in its explanation can be distinguished by the locus of control or control center. Perceived behavioral control can be determined by individual beliefs about the availability of resources in the form of equipment, compatibility, control beliefs strength that support or inhibit the behavior to be predicted and the amount of power of 
control factors in realizing this behavior [14]. Jogiyanto (2008) explains that according to this theory, these beliefs can be based on past experiences with behavior and are also influenced by second-hand information about behavior, by observing the experiences of friends and friends, and with the factors that increase or decrease perceived difficulty in performing the behavior [10].

\subsection{Purchase Intention}

The intention is defined as the desire to perform a behavior. The intention is not yet in the form of behavior. Intentions are not always static and may change over time. While behavioral intention in the context of consumer behavior can be defined as the desire of consumers to behave in a certain way to own, dispose of, and use a product or service [15]. Consumer purchase intentions fall into two categories: (1) Neither product nor brand and (2) Product class only (for example, there is an intention to buy ice cream, but additional decisions have to be made regarding what type and brand) [5]. Category 1 intentions is generally referred to as a fully planned purchase. Category 2 intentions are planned purchases even if the choice of brand is made at the point of sale.

\subsection{Factors influencing purchase intention}

Hawkins and Mothersbaugh (2013) in their research stated that three factors may influence purchase intentions, namely: social factors, marketing activities, and personal factors. Social factors consist of five variables, namely: culture, demographics, social class, reference groups, and family [16]. Culture is all values, thoughts, symbols that influence the behavior, attitudes, beliefs and habits of a person and society. Culture consists of two indicators, namely trends and lifestyle. Demographics will describe the characteristics of a population such as age, religion, ethnicity, and so on. Demographics have three indicators, namely activity, level of education, and age [17]. Kotler and Armstrong (2016) state that social class is a relatively permanent and tiered division of society in which members share the same values, interests and behaviors. The social class consists of three indicators, namely prestige, social status and income level [12]. A reference group can be defined as an individual or group of people who significantly influence a person's behavior, and family is defined as the environment where most consumers live and interact with other family members. The indicators contained in the reference group are the influence of 
friends and the influence of social media friends, while the indicator contained in family factors is the influence of relatives [18].

Service marketing factors according to Lovelock et al. (2011) consists of eight elements, namely: product, place and time, price, promotion and education, process, physical envorontment, personnel, and production capacity. Product element is everything offered to the market to attract attention, acquisition, use, or consumption that can satisfy a desire or need [12]. The indicators contained in product elements are taste, quality quality, aroma, product variation, shape/appearance, food texture, clear menu list information and prices. Meanwhile, services are a form of product that consists of activities, benefits, or satisfaction that are offered for sale and are intangible and do not result in ownership of something. Service products consist of core products, additional services, and service processes [19]. Place and time, which means to deliver service elements to customers, decisions must be made about where and when it is done and also the methods and channels used. The indicators for place and time are that the location is easy to reach, and is open every day. Price, is the amount of money that must be paid to obtain the right to use the product. Price has two indicators, namely affordable price and price according to taste/value [16]. Promotion and education have three important roles, namely as a provider of information and advice needed, convincing target customers of the goodness of a brand or product, and encouraging them to take action within a certain time. Promotion and education have only one indicator which is wellknown publicity. Process, creating and delivering product elements requires effective process design and implementation to avoid low productivity and service failures. The indicators contained in the process factor are the ease of ordering and the speed of service. Physical environment, service companies must carefully manage the physical environment in the form of the appearance of buildings, parks, vehicles, interior furniture, equipment, employee uniforms, signs, printed materials and various other signs as tangible evidence of the quality of the services offered. Physical environmental factors have three indicators, namely the design of the place, atmosphere, and supporting facilities. Personnel, as service providers, will always need direct interaction between customers and service employees. Service providers need to work closely with the human resources department and pay particular attention to selecting, training and motivating their employees. The indicators contained in the human factor are friendliness, responsive service, neat, polite and polite clothes. Production capacity, the company can face a situation of limited capacity in the 
form of different supply and demand, such as the demand that exceeds the ideal capacity or demand is less than ideal so that the company's capacity is unemployed. The production capacity factor has two indicators, namely operational time and visitor circulation system [19].

Personal factors consist of sevent elements, namely: perception, learning, memory, motive, personality, emotions, attitude. Perception can be defined as the individual's process of receiving and giving meaning to stimuli (stimuli). The indicators contained in the perception factor are assumptions and impressions [20]. Learning is a change in a person's behavior that arises from experience. The indicator contained in the learning factor is experienced [12]. The memory according to Hawkins and Mothersbaugh (2013) is the total result of accumulated previous learning experiences and consists of two interrelated components, namely short-term memory and long-term memory [16]. The indicators contained in the memory are re-purchase and recall. A motive is a need with strong pressure that encourages a person to seek satisfaction from that need. The indicator contained in the motive is desire [12]. Personality according to Kotler and Keller (2016) is a set of human psychological traits that cause relatively consistent and long-lasting responses to environmental stimuli (including purchasing behavior) [21]. The indicator contained in personality is belief. Emotion according to Hawkins and Mothersbaugh (2013) is strong, tends to feel uncontrolled and affects behavior [16]. Indicators contained in emotional factors are situations and feelings. According to Sumarwan (2011) attitude is an expression of consumer feelings about an object whether it is liked or not and attitudes can also describe consumer confidence in various attributes and benefits of the object. [18]. Attitude has two indicators, namely habits and preferences.

Based on several variables been described, Fadhilah (2017) analyzed these variables using factor analysis and was found nine new variables, namely: product-price-personal quality, operational exellence, prestige, physical environment, product appearance, lifestyle, psychological, promotion, and image [22]. Furthermore, the factors formed are analyzed, then linked in purchasing decision making. Based on the Fadhilah's (2017) research, it was found the factors having the most dominant level of contribution in the purchasing decision making process. There are three factors having most dominant in the purchasing decision-making process, namely: (1) The productprice-personal quality which consists of 15 indicators (the taste of the product is delicious and delicious, the quality of the product is guaranteed, the aroma of the product is appetizing, the texture of the product is soft and crunchy, clear 
menu and price list information, affordable product prices, prices according to the taste/value of the products offered, employee friendliness, the perceived quality of the product is good, the experience of buying similar products, repurchasing products because of their quality and delicacy, recalling impressions that have been received, fulfilling wishes, confidence in product quality, and likes the product) with an eigenvalues value of 14,575 and able to explain 35,549\% variation; (2) Operational excellence which consists of 6 indicators (open every day, ease of ordering, speed of service, fast service response, long operational time, and good visitor circulation system) with eigenvalues of 3,382 and able to explain $8,248 \%$ of variations; (3) Prestige which consists of 4 indicators, (according to education level, according to age, prestige with people around you, and social status) with eigenvalues of 3.097 and able to explain $7.553 \%$ of the variation. Then in this study, the factors produced by Fadhilah (2017) were analyzed using SEM-PLS to determine which factors affect consumer purchase intentions based on attitudes, subjective norms and behavioral control (Theory Planned Behavior).

\subsubsection{Product-Price-Personal Quality}

Product quality is the ability of a product to demonstrate its function, which includes overall durability, reliability, accuracy, ease of operation and product repair, and other product attributes [21]. Product quality is the overall features and characteristics of a product or service that relies on its ability to satisfy consumer needs [23]. According to Joel et al. (2017), product quality has a significant effect on purchase intention [24]. Waluya et al. (2019) state that to identify price effects of product quality, product cost, and product safety on customer satisfaction in the United States, the automotive industry is one of the most numerous industries [25]. The most prominent factors to influence purchase intent of online shopping can refer to product quality, product prices, product features, and others [26]. Apart from having a direct effect on purchase intention, product quality can also indirectly influence purchase intention through several intervening variables in the theory of planned behavior, specifically attitude toward behavior (Y1), subjective norms (Y2), and perceived behavioral control (Y3) [27]. An example of the effect of product quality on purchase intention is through attitude toward behavior, namely the provision of price discounts where consumers can save money and get highquality products at lower prices [28]. Based on this statement, a hypothesis can be formed: 


$\begin{aligned} & \text { Hypothesis 1a: } \text { Product-price-personal quality variable (X1) influence } \\ & \text { purchase intention (Z1) } \\ & \text { Hypothesis 1b1: Product-price-personal quality variable (X1) influence } \\ & \text { purchase intention (Z1) through attitude (Y1) } \\ & \text { Hypothesis 1b2: Product-price-personal quality variable (X1) influence } \\ & \text { purchase intention (Z1) through subjective norms (Y2) } \\ & \text { Hypothesis 1b3: Product-price-personal quality variable (X1) } \\ & \text { influence purchase intention (Z1) through perceived } \\ & \text { behavioral control (Y3) }\end{aligned}$

\subsubsection{Operational Excellence}

Operational excellence refers to the services provided to customers. Mangla et al. (2020) state that operational excellence helps managers implement sustainable operational strategies and better understand trade-offs by applying a holistic sustainable business perspective [29]. Service quality is something that is perceived by customers. Customers will judge the perceived quality of a service based on what they describe in their minds [30]. Service quality is a consumer evaluation of service performance perfection. Service quality is dynamic, which changes according to customer demands [31]. Geddie states that the quality of services provided will affect a person in making purchases. Service quality is the difference between customers' expectation and their perceived performance of a service [31]. The quality of service according to Han and Kim (2010) is an important thing that can affect attitude toward switching and consumer satisfaction in purchasing behavior [32]. Thus, indirectly, operational excellence can also influence purchase intention through the intervening variables contained in the theory of planned behavior. Therefore, a hypothesis can be formed:

Hypothesis 2a: Operational excellence (X2) influence purchase intention (Z1) Hypothesis 2b1: Operational excellence (X2) influence purchase intention (Z1) through attitude (Y1)

Hypothesis 2b2: Operational excellence (X2) influence purchase intention (Z1) through subjective norms (Y2)

Hypothesis 2b3: Operational excellence (X2) influence purchase intention (Z1) through perceived behavioral control (Y3)

\subsubsection{Prestige}

In choosing a brand, consumers will choose a certain brand that reflects or strengthens their identity so that they are accepted in a particular community or to increase the prestige of that individual individually [33]. Prestige brand is 
defined as the product/service status associated with a particular brand [34]. Dubois and Czellar also express the word 'prestige' as a subjective evaluative assessment of the high social status of people or inanimate objects such as branded objects [35]. O' Cass and Frost stated that some of the prestigious and non-prestigious brands can influence consumer purchase motivation to increase their social status and self-expression [36]. Global brands are often associated with higher quality and prestige. Perceived quality is the customer's subjective in evaluating the overall superiority of a product [37]. Global brands are associated with higher prestige [38]. This is because they are indeed higherpriced, rarer, and more expensive than local brands, which in turn creates aspirations for greater prestige appeal [39]. Hsu et al. (2017) explained that there is an indirect relationship between prestige and purchase intention which is influenced by the variables contained in the theory of planned behavior on green skincare products. The interaction effect between attitude, subjective norm, and perceived behavioral control purchase intention of green skincare products were significantly positive [40]. Based on the stated above, the following hypotheses have been developed:

Hypothesis 3a: Prestige (X3) influence purchase intention (Z1)

Hypothesis 3b1: Prestige (X3) influence purchase intention (Z1) through attitude (Y1)

Hypothesis 3b2: Prestige (X3) influence purchase intention (Z1) through subjective norms (Y2)

Hypothesis 3b3: Prestige (X3) influence purchase intention (Z1) through perceived behavioral control (Y3)

\subsection{Relationship between attitude toward behavior, subjective norms on behavior, and perceived behavior control toward purchase intention}

TPB has described the relationship between attitude, subjective norms, and perceived behavior control toward purchase intention. Moreover, Fachruddin (2014) in his research explains that there is a positive relationship between attitude and subjective norms on purchase intention of dried chilies in Bogor traditional markets [41]. Another study that explains the relationship between attitude, subjective norms, perceived behavior control on purchase intention is Tarkiainen and Sundqvist (2005) which explain that health awareness makes consumers have an attitude towards buying towards the intention to buy organic food. Subjective norms in Tarkiainen and Sundqvist's (2005) study also affect the attitude of a consumer in buying organic food [42]. Paul et al. (2016) in their research also states that there is a positive relationship between the attitude of consumers in consuming green products and their 
purchase intentions of the product. The relationship between environmental awareness and all the variables contained in the theory of planned behavior showed a significant result on buying intention of green products [43]. Haro (2016) states that perceived behavior and attitude control has a significant and positive value on purchase intention. Meanwhile, subjective norms, availability, and information have insignificant value on a person's buying interest in halal products [44].

\section{Research Methods}

Based on the background and objectives outlined earlier, the framework is shown in Figure 3.

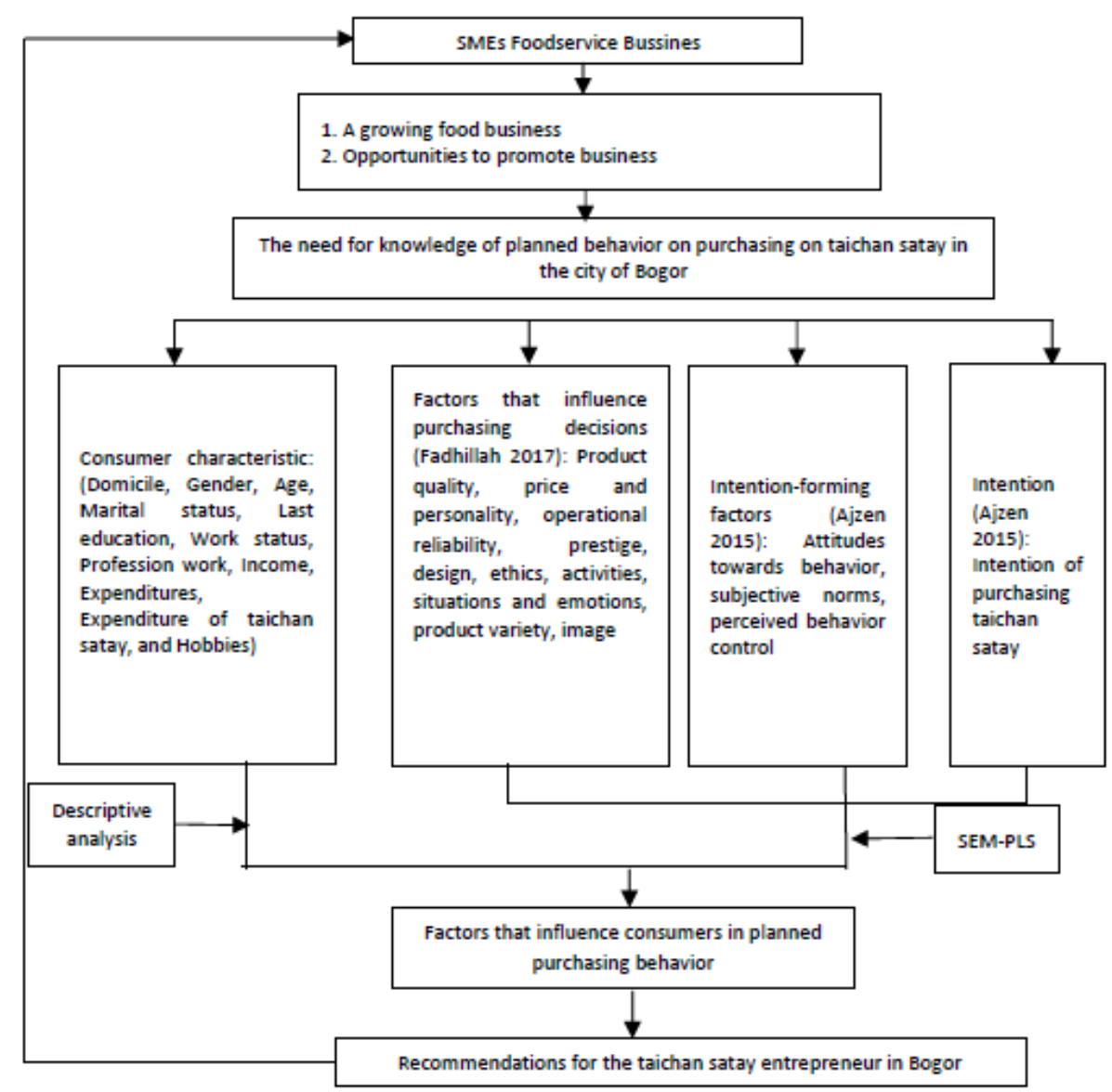

Fig. 3. Framework 


\subsection{Framework}

Taichan's Satay is a type of food business developing in the city of Bogor The opportunity to advance the Taichan's Satay business in the city of Bogor is a driving force for the need for research so that the Taichan's Satay business in Bogor can improve services for the progress of their business. One of them can be identified by mapping, knowing, and fulfilling what consumers expect and want through consumer behavior. The consumer behavior, especially about the planned purchasing behavior of Taichan's Satay in Bogor City, with the factors that influence it.

This study adopts variables from previous research of Fadhilah (2017) using the object of Maranggi's satay entrepreneurs in Bogor City which was examining the factors contributing on purchasing decisions. Meanwhile this research will focus more on factors influencing planned purchasing behavior with the object of the Taichan's Satay entrepreneur in Bogor City. The independent variable is based on new variables resulting from previous research conducted by Fadhilah (2017) and the dependent variable is based on the TPB of Ajzen (2015). This research will produce purchasing decision factors that influence planned purchasing behavior and the most dominant in planned purchasing behavior, then it will be used as recommendations for restaurant or food-street entrepreneurs as SME's representative.

\subsection{Research Place and Time}

The research was conducted on four objects of Taichan's Satay entrepreneur in Bogor City, namely Asin X Taichan, Bogor Taichan Shop, Bangor Taichan's Satay and Bang Gondrong Taichan's Satay. Data collection was carried out from October to November 2017. The selection of the four objects was based on the feasibility of the place of business to be examined in terms of its existence which included the length of the business, the crowd of visitors and their respective concepts.

\subsection{Data Collection Types and Methods}

The type of data used in this study is primary and secondary data. Primary data were obtained by conducting structured interviews with business owners and filling in questionnaire by respondents who had bought Taichan's satay on four objects of the Taichan's satay entrepreneur. Secondary data were obtained from BPS data for Bogor City in 2018, and related internet sources. The data collection technique used structured interviews by using open and closed questionnaires. In this study, only three variables were used that contributed the most to purchase intention. The contribution value of the total 
of the three variables has exceeded 50\%. The three variables are product-pricepersonal quality, operational excellence, and prestige.

\subsection{Sample Determination}

The sample used in this study is limited to respondents with planned purchases. To get respondents with pre-planned purchases, screening was carried out using six questions adapted from Mick (1996) in Sunyoto (2014) to be able to find out the characteristics of someone's purchase, whether it is the characteristics of consumers who make purchases with planning or purchases without planning (impulse buying), by changing the items according to the needs and the minimum age of the respondents is limited to starting from 15 years.

The sampling technique in this research is accidental sampling. Sampling in this research uses the theory of Sunyoto (2014), the number of indicators multiplied by 5 [45]. The sample used in this study is limited to respondents with planned purchases. To get respondents with planned purchases, screening has been carried out using six questions adapted from Suryani (2013) to find out the characteristics of a person's purchases whether referred to in the characteristics of consumers who make purchases with planning or unplanned purchases (impulse buying), with changes in questions as needed [46].

\subsection{Methods of Processing and Data Analysis}

Data processing and analysis in this research begins with a validity test and a reliability test whose results indicate the data to be analyzed is valid and reliable. The validity test is used to determine the feasibility of items in a list of questions in defining a variable [47]. This questionnaire generally supports a certain group of variables and the validity test should be done on each item of the question. Reliability tests were conducted on questions to determine the consistency of measuring instruments in measuring the same symptoms or to determine the level of measurement error [48]. Reliability is an index number that shows the consistency of a measuring device in measuring the same symptoms.

This research goes through two steps. The first analysis is a descriptive analysis that is used to test the characteristics of Taichan's Satay consumers. The second analysis is variance-based SEM by using Smart SEM-PLS software. According to Jogiyanto and Abdillah (2015), PLS is a structure variance-based equation analysis which is a measurement model and structure model test. Its specification model consists of the inner model, outer model, and weight relation [49]. The inner model shows the causal relationship among latent 
variables (structure model). The outer model shows the relationship between the indicator and latent variable (measurement model). Weight relation shows the relationship indicator-between-variance with latent variable. The second analysis is used to understand the factors that influence purchasing decisions, the factors that influence planned purchases that contain the factors forming an intention, and purchase intention on Taichan's Satay consumers in Bogor City. The results of this second analysis will produce managerial implications of purchases of planned purchases by Taichan's Satay buyers in Bogor City.

\section{Results and Discussion}

This research was conducted to obtain information about the factors that influence planned purchase behavior by taking four samples of Taichan's Satay. This research obtained information related to the general description of the object of research, consumer characteristics, SEM Analysis on SMEs food, evaluation of measurement models (outer model), evaluation of measurement models (inner model), and significant hypotheses.

\section{Consumer Characteristics}

The characteristics of consumers in the study are distinguished based on domicile, gender, age, marital status, last education, employment status, occupational profession, type of work, monthly income, average monthly expenditure, average monthly expenditure for purchasing maranggi satay and Taichan's Satay, and hobbies.

The characteristics of Taichan's Satay consumers are dominated by the people with the domicile of Bogor City as much as $70.4 \%$. The biggest percentage of consumers by gender is women with a percentage of $64.6 \%$. The dominant age of consumers is in the age range of $21-25$ years with $47.5 \%$. In the marital status category, Taichan's Satay consumers are dominated by consumers with $90 \%$ unmarried status. The educational status of the majority of high school/vocational/equivalent students is $29.2 \%$. In the occupational or professional category, Taichan's Satay consumers are dominated by students with a percentage of work $56.6 \%$ and a percentage of professions $54.9 \%$. The average monthly income and expenditure for consumers are in the range of Rp1,000,000 - Rp2,000,000 with a percentage of 35.4\% and 42.4\%. The dominant consumer uses an average expenditure to buy Taichan's Satay as much as IDR 50,000 - IDR 100,000. The most dominant hobby owned by consumers is culinary tourism as much as Rp. $18.3 \%$.

\section{SEM Analysis of SMEs Food}


This research is through the latent variable variance test stage because of the multi-correlation caused by a complex model, so it is necessary to modify the model. The latent variable in this study consists of Product-price-personal quality (X1), operational excellence (X2), prestige (X3) and purchase intention (Z1). The intervening latent variable consists of attitude (Y1), subjective norms (Y2), control of perceived behavior (Y3). To determine the effect between these variables, an SEM analysis was performed which would be tested by assessing the outer model and inner model.

\section{Evaluation of Measurement Models (Outer Model)}

The step for the evaluation of the measurement model is using Composite reliability, Average variance extracted (AVE), Factor loadings, and HTMT to evaluate the construct measures' internal consistency reliability and assessment of validity. Hair et al. (2018) states that to determine internal consistency reliability, some conditions must be met, namely having a Cronbach's alpha value or a Composite reliability value of at least 0.7 [50]. The validity assessment is carried out by converging validity when each indicator has an external load above 0.70 and when each of the mean extracted variance constructs (AVE) is 0.50 or higher. Based on the variance matrix of latent variables, it shows that there are some exogenous latent variables $(\mathrm{X})$ that are covariant $<0.5$ to all intervening latent variables $(\mathrm{Y})$ so that the exogenous latent variables (X) must be eliminated [50]. Based on the research results, Composite reliability, and AVE are presented in Table 2.

Table 2. Composite Reliability, Average Variance Extracted (AVE)

\begin{tabular}{lcc}
\hline \multicolumn{1}{c}{ Latent Variable } & $\begin{array}{c}\text { Composite } \\
\text { Reliability }\end{array}$ & $\begin{array}{c}\text { Average Variance } \\
\text { Extracted (AVE) }\end{array}$ \\
\hline Product quality, price, and personal (X1) & 0.931 & 0.628 \\
Operational excellence (X2) & 0.915 & 0.685 \\
Prestige (X3) & 1.000 & 1.000 \\
Attitude (Y1) & 0.909 & 0.834 \\
Subjective norms (Y2) & 0.896 & 0.742 \\
Control of perceived behavior (Y3) & 0.828 & 0.616 \\
Purchase intention (Z1) & 0.810 & 0.682 \\
\hline
\end{tabular}

Source: Data processed by PLS-SEM (2020)

The validity value is also seen from the loading factor value. Hair et al. (2018) stated that the factor loading value must be $\geq 0.708$ [50]. Based on this statement, if the loading factor value of some indicators is less than 0.708 then the indicators must be discarded. The loading factor on all indicators in this study has met the requirements because the value is greater than 0.708 . The 
results of the assessment of factor loading on each indicator are shown in Appendix 1.

The next measurement is evaluation using discriminant validity. Hair et al. (2018) states that the discriminant validity measurement can use the heterotrait-monotrait ratio (HTMT) [50]. The limit of the conditions used for conceptually similar constructs is $<0.90$, while for conceptually different constructs the specified limit is $<0.85$. The HTMT value on all variables in this study was below the predetermined limit, namely $<0.85$. The results of the assessment of HTMT on each variable are shown in Table 3.

Table 3. HTMT Results

\begin{tabular}{lcccccr}
\hline & X1 & X2 & X3 & Y1 & Y2 & Y3 \\
\hline Product quality, price, and personal (X1) & & & & & & \\
Operational excellence (X2) & 0.588 & & & & & \\
Prestige (X3) & 0.206 & 0.255 & & & & \\
Attitude (Y1) & 0.396 & 0.370 & 0.288 & & & \\
Subjective norms (Y2) & 0.297 & 0.282 & 0.344 & 0.649 & & \\
Control of perceived behavior (Y3) & 0.485 & 0.305 & 0.239 & 0.407 & 0.372 & \\
Purchase intention (Z1) & 0.807 & 0.395 & 0.275 & 0.580 & 0.502 & 0.636 \\
\hline
\end{tabular}

Source: Data processed by PLS-SEM (2020)

\section{Evaluation of Structural Models (Inner Model)}

Inner model evaluation is an analysis that describes the relationship between latent variables. The structural model in PLS is evaluated using $\mathrm{R}^{2}$ value, and $\mathrm{Q}^{2}$ value [50]. The value of $\mathrm{R}^{2}$ is used to measure the degree of variation in changes in exogenous variables against endogenous variables. The criteria for limiting the $\mathrm{R}^{2}$ value are divided into three classifications, namely the value of 0.75 as substantial, 0.50 as moderate, and 0.25 as weak. An $\mathrm{R}^{2}$ value of 0.90 and higher is a typical indication of over-fitting. The endogenous variable in this study is purchase intention (Z1) while the exogenous is product quality, price and personal (X1), operational excellence (X2), and prestige (X3). The $\mathrm{R}^{2}$ value in this study was classified as weak because it was $<0.50$, namely 0.428 . The value of $R^{2}$ in the endogenous variable can be seen in Table 4 .

Tabel 4. R2 Value

\begin{tabular}{cc}
\hline & R-square $\left(\mathrm{R}^{2}\right)$ \\
\hline Purchase intention (Z1) & 0.428 \\
\hline Source: Data processed by PLS-SEM (2020)
\end{tabular}

The next measurement to calculate the model structure is to use predictive relevance or cross-validated redundancy $(\mathrm{Q} 2)$. The result shows that the value 
of all latent constructs has a good predicative relevance because of values larger than zero. The Q2 value of all variables in this study can be seen in Appendix 2.

The path coefficient values of the moderated effect reveal the strength of the relationship between the two constructs when the moderator variable has a value of 0 if the researcher follows standard procedures and standardizes the moderator indicators before analysis [51]. Path coefficient values are standardized in the range from -1 to +1 , with coefficients closer to +1 indicating a strong positive relationship and coefficients closer to -1 indicating a strong negative relationship [52]. Based on the research results, the evaluation of the path coefficient, mean, standard deviation and $t_{\text {statistics }}$ are presented in Table 5.

Table 5. Results of the path coefficient, mean, standard deviation and $t_{\text {statistics }}$

\begin{tabular}{lccccc}
\hline & $\begin{array}{c}\text { Original Samp } \\
\text { Path coefficie } \\
(\mathrm{O})\end{array}$ & $\begin{array}{c}\text { Sample Mea } \\
(\mathrm{M})\end{array}$ & $\begin{array}{c}\text { Standard Deviati } \\
(\mathrm{STDEV})\end{array}$ & $\begin{array}{c}\text { T Statistics } \\
(|\mathrm{O} / \mathrm{STDEV}|\end{array}$ & P Values \\
\hline X1 -> Y1 & $\mathbf{0 . 2 2 7}$ & $\mathbf{0 . 2 2 2}$ & $\mathbf{0 . 0 8 2}$ & $\mathbf{2 . 7 5 3}$ & $\mathbf{0 . 0 0 6}$ \\
X1 -> Y2 & $\mathbf{0 . 1 5 8}$ & $\mathbf{0 . 1 5 2}$ & $\mathbf{0 . 0 7 8}$ & $\mathbf{2 . 0 1 9}$ & $\mathbf{0 . 0 4 4}$ \\
X1 -> Y3 & $\mathbf{0 . 3 4 1}$ & $\mathbf{0 . 3 4 3}$ & $\mathbf{0 . 0 9 6}$ & $\mathbf{3 . 5 6 2}$ & $\mathbf{0 . 0 0 0}$ \\
X1 -> Z1 & $\mathbf{0 . 4 9 7}$ & $\mathbf{0 . 5 0 4}$ & $\mathbf{0 . 0 7 4}$ & $\mathbf{6 . 7 0 0}$ & $\mathbf{0 . 0 0 0}$ \\
X2 -> Y1 & $\mathbf{0 . 1 5 0}$ & $\mathbf{0 . 1 5 8}$ & $\mathbf{0 . 0 6 6}$ & $\mathbf{2 . 2 8 3}$ & $\mathbf{0 . 0 2 3}$ \\
X2 -> Y2 & 0.095 & 0.105 & 0.073 & 1.298 & 0.195 \\
X2 -> Y3 & 0.038 & 0.040 & 0.070 & 0.536 & 0.592 \\
X2 -> Z1 & -0.070 & -0.070 & 0.070 & 0.995 & 0.320 \\
X3 -> Y1 & $\mathbf{0 . 1 8 1}$ & $\mathbf{0 . 1 8 1}$ & $\mathbf{0 . 0 7 6}$ & $\mathbf{2 . 3 8 7}$ & $\mathbf{0 . 0 1 7}$ \\
X3 -> Y2 & $\mathbf{0 . 2 6 0}$ & $\mathbf{0 . 2 6 1}$ & $\mathbf{0 . 0 6 4}$ & $\mathbf{4 . 0 8 2}$ & $\mathbf{0 . 0 0 0}$ \\
X3 -> Y3 & 0.123 & 0.120 & 0.080 & 1.539 & 0.124 \\
X3 -> Z1 & -0.096 & -0.102 & 0.070 & 1.373 & 0.170 \\
Y1 -> Z1 & 0.149 & 0.143 & 0.081 & 1.840 & $\mathbf{0 . 0 6 6}$ \\
Y2 -> Z1 & $\mathbf{0 . 1 3 5}$ & $\mathbf{0 . 1 3 8}$ & $\mathbf{0 . 0 6 1}$ & $\mathbf{2 . 2 0 9}$ & $\mathbf{0 . 0 2 8}$ \\
Y3 -> Z1 & $\mathbf{0 . 1 5 6}$ & $\mathbf{0 . 1 5 7}$ & $\mathbf{0 . 0 6 4}$ & $\mathbf{2 . 4 4 8}$ & $\mathbf{0 . 0 1 5}$
\end{tabular}

Source: Data processed by PLS-SEM (2020)

Based on Table 5, there are 9 significant relationships between several variables because they have a value of $<0.05$, namely the relationship between product quality, price, and personal (X1) on attitude (Y1), product quality, price, and personal (X1) on subjective norms (Y2). ), product quality, price, and personal (X1) towards perceived behavior control (Y3), product quality, price, and personal (X1) on purchase intention (Z1), operational excellence (X2) 
towards attitude (Y1), prestige ( X3) towards attitude (Y1), prestige (X3) towards adjective norms (Y2), adjective norms (Y2) on purchase intention (Z1), and perceived behavior control (Y3) towards purchase intention (Z1). The relationship between variables that have a value $<0.1$ can be said to be marginally supported 53. Based on this statement, the relationship between attitude (Y1) towards purchase intention (Z1) is significant because it has a value of 0.066 . The complete picture of the relationship between latent and nonlatent variables can be seen in Figure 4. The bold lines show a significant relationship while those that are not bold show no significant relationship.

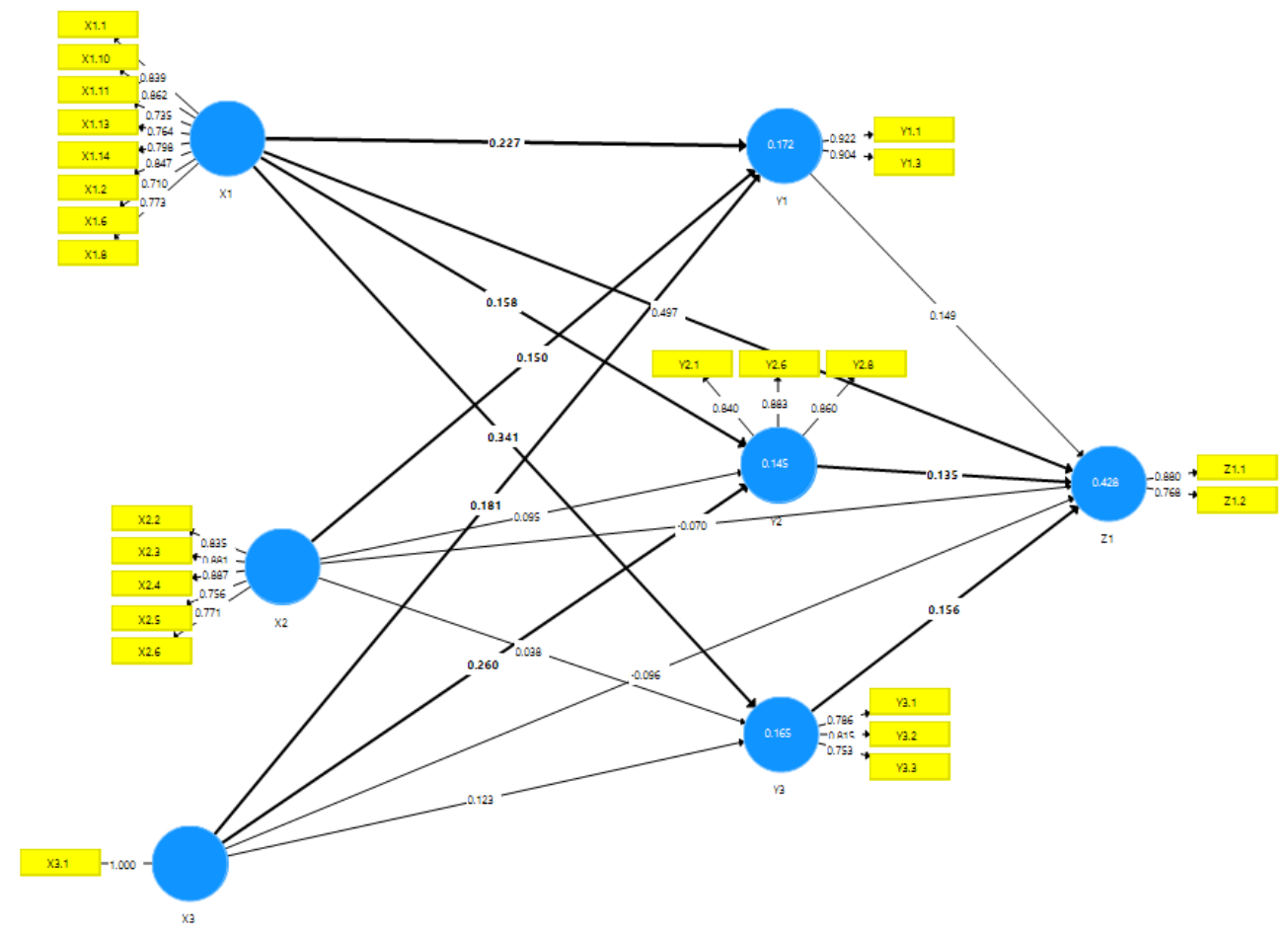

Fig. 4. Path Coefficient

Based on Table 6 , the results obtained from the hypothesis show a significant relationship between the exogenous latent variable $(\mathrm{X})$ to the intervening latent variable $(\mathrm{Y})$, then the intervening latent variable $(\mathrm{Y})$ to the endogenous latent variable $(Z)$. The hypotheses that get a significant result are H1a: Product quality, price, and personal variable (X1) influence purchase intention (Z1), H1b2: Product quality, price, and personal variable (X1) influence purchase intention (Z1) through subjective norms (Y2) ), H1b3: Product quality, price, and personal variable (X1) influence purchase intention 
(Z1) through perceived behavioral control (Y3), and H3b2: Prestige (X3) influence purchase intention (Z1) through subjective norms (Y2).

Table 6. Hypotheses result

\begin{tabular}{|c|c|c|}
\hline Hypotheses & Result & Conclusion \\
\hline $\begin{array}{l}\text { Hypothesis 1a: Product quality, price, and } \\
\text { personal variable (X1) influence } \\
\text { purchase intention (Z1) }\end{array}$ & Significant & Supported \\
\hline $\begin{array}{l}\text { Hypothesis } 1 \mathrm{~b} 1 \text { : Product quality, price, and } \\
\text { personal variable (X1) influence } \\
\text { purchase intention }(\mathrm{Z} 1) \text { through attitude } \\
\text { (Y1) }\end{array}$ & Not significant & $\begin{array}{l}\text { Marginally } \\
\text { supported }\end{array}$ \\
\hline $\begin{array}{l}\text { Hypothesis } 1 \mathrm{~b} 2 \text { : Product quality, price, and } \\
\text { personal variable }(\mathrm{X} 1) \text { influence } \\
\text { purchase intention } \\
\begin{array}{l}\text { subjective norms (Y2) } \\
\text { surough }\end{array}\end{array}$ & Significant & Supported \\
\hline $\begin{array}{l}\text { Hypothesis 1b3: Product quality, price, and } \\
\text { personal variable (X1) influence } \\
\text { purchase intention (Z1) through } \\
\text { perceived behavioral control (Y3) }\end{array}$ & Significant & Supported \\
\hline $\begin{array}{l}\text { Hypothesis 2a: Operational excellence (X2) } \\
\text { influence purchase intention }(\mathrm{Z} 1)\end{array}$ & Not significant & Not supported \\
\hline $\begin{array}{l}\text { Hypothesis 2b1: Operational excellence } \\
\text { (X2) influence purchase intention (Z1) } \\
\text { through attitude (Y1) }\end{array}$ & Not significant & Not supported \\
\hline $\begin{array}{l}\text { Hypothesis 2b2: Operational excellence } \\
\text { (X2) influence purchase intention ( } 1 \text { ) } \\
\text { through subjective norms (Y2) }\end{array}$ & Not significant & Not supported \\
\hline $\begin{array}{l}\text { Hypothesis 2b3: Operational excellence } \\
\text { (X2) influence purchase intention (Z1) } \\
\text { through perceived behavioral control } \\
\text { (Y3) }\end{array}$ & Not significant & Not supported \\
\hline $\begin{array}{l}\text { Hypothesis 3a: Prestige (X3) influence } \\
\text { purchase intention (Z1) }\end{array}$ & Not significant & Not supported \\
\hline $\begin{array}{l}\text { Hypothesis 3b1: Prestige (X3) influence } \\
\text { purchase intention (Z1) through attitude } \\
\text { (Y1) }\end{array}$ & Not significant & Not supported \\
\hline $\begin{array}{l}\text { Hypothesis 3b2: Prestige (X3) influence } \\
\text { purchase intention (Z1) through } \\
\text { subjective norms (Y2) }\end{array}$ & Significant & Supported \\
\hline $\begin{array}{l}\text { Hypothesis 3b3: Prestige (X3) influence } \\
\text { purchase intention (Z1) through } \\
\text { perceived behavioral control (Y3) }\end{array}$ & Not significant & Not supported \\
\hline
\end{tabular}

The results showed that product quality, price and personal (X1) had a direct effect on purchase intention (Z1). This means that the quality of the 
Taichan's Satay and the price is given make someone intend to buy it. Wang and Chen (2004) stated that the perception of Chinese consumers about product quality is a predictor that influences their purchase intention for both local and foreign products [53]. Product quality is an intrinsic and extractive indicator that consumers can consider to evaluate the performance of a company [54]. Quality resembles the functional value of a product, which in turn motivates consumers to make choices [53]. The results showed that there was a significant relationship between product-price-personal quality (X1) on purchase intention (Z1) through subjective norms (Y2), and perceived behavior control (Y3) but not significant when going through attitudes (Y1). The relationship between product quality, price and personal (X1) on purchase intention (Z1) when going through attitude (Y1) it can be said to be marginally supported because it has a value $<0.10$ [55].

In the purchase of Taichan's Satay, product-price-personal quality are factors that previously improved the perceived behavior control of consumers, one of the consumers' perceptions to feel easy and not difficult to buy Taichan's Satay is caused by their trust and reasons because of the good quality of satay product, especially on the aroma and the taste of Taichan's Satay is delicious, but also because of the quality of Taichan's Satay is guaranteed. Furthermore, this perceived behavioral control increases consumer purchase intentions. So, this shows that indirectly the product quality, price and personal are factors that also increase the consumer's purchase intention. In previous studies conducted by Iskandar et al. (2015) shows that product quality is one of the main factors influencing satisfaction and purchase intention of a food product [56]. Customer satisfaction can influence one's intentions in purchasing. The experience of purchasing the same product is one of the indicators found in product quality, price, and personal factors. Saleem et al. (2015) stated that customer satisfaction acts as a partial mediating variable in the relationship between product quality and purchase intention [57]. Other studies have stated that customer satisfaction with halal products also has a positive effect on someone's buying intentions for these products [58].

Prestige has indirectly influence on a person's purchase intention. The results showed that prestige can influence a person's buying interest through intervening variables of subjective norms. This means that a person's intention in purchasing Taichan's satay can be influenced by his prestige on the product which is also influenced by the prevailing norms. Several other studies have explained that there is a positive relationship between prestige and a person's purchase intention. For example, Hwang and Han (2016) through their research found a model to investigate the importance of brand prestige using a total of 1500 observations in the retail industry. The results revealed that brand prestige 
has a positive influence on perceived quality, which in turn positively affects purchase intention [59]. Traders of Taichan's satay generally sell their products using a wheelbarrow on the side of the road, this allows one's prestige to be a determining factor that can influence the intention to buy taichan satay. Chien et al. (2012) explained that prestige can affect the purchase intention of tourists in Vietnam in determining lodging places, the determination of lodging places is also based on subjective norms [60]. Several indicators on the prestige variable that might affect a person's purchase intention are education level, age, and social status.

Based on age, the prestige variable can affect a person's purchase intention in purchasing Taichan's satay because most of the buyers of taichan satay are young people. This is because the taichan satay selling place is used as a place to hang out by some young people. The selling place for taichan satay is often used for young people to gather because of the store atmosphere created by the seller so that these people feel at home for a long time in the shop. Hussain and Ali (2015) state that store atmosphere created in retail outlets makes a buyer feel comfortable in the store so that it can lead to someone's purchase intention [61]. The Taichan's satay trader who sells his meat on the side of the road can also influence a person's purchase intention based on their social status. According to Triandewi and Tjiptono (2013), a person will buy or consume luxury goods to differentiate themselves by creating their reference group as well as to separate from other groups based on their social status [62]. This proves that some people feel prestigious if they buy Taichan's satay by the side of the road. Prestige also has a significant effect on attitude (Y2) but not significantly on purchase intention (Z1).

Operational excellence when viewed from the results obtained does not directly affect a person's purchase intention. Based on these results, operational excellence is only significant for the attitude variable (Y1). Operational excellence has several indicators that can make this factor affect a person's purchase intention. Several studies have shown that there is a relationship between operational excellence and one's purchase intention. The quality of services provided will affect a person in making purchases. Service quality is the difference between customers' expectation and their perceived performance of a service [31]. Khanifar et al. (2012) in their research also explained that there is a direct relationship between e-service quality and subjective norms in the intention to use e-banking where both of them have quite high scores. In his research, e-service quality and subjective norms also influence the intention to use e-banking [63]. Other research states that service quality, which is part of operational excellence, has a positive effect on purchase intention, for example, 
a study conducted by Rostami et al. (2014) states that service quality affects consumers' intention to use electronic banking [64].

The state of the place is included in the store atmosphere which is one of the things that affects one's purchase intention. Hussain and Ali (2015) explain the factors that influence the store atmosphere, namely, cleanliness, music, absence of scent, display, lighting, and color [61]. Cleanliness is one of the influences of one's intention to buy taichan satay, because in general, taichan satay is sold on the side of the road which makes someone doubt its cleanliness. Customers can create positive or negative word of mouth about an outlet or retail because of their cleanliness [65]. Traders usually display their places and products so that they can attract buyers. Place display is very influential on a consumer's interest to come to the store. Watanabe et al. (2019) stated in their research that place layout in supermarkets and consumer satisfaction has a significant effect on consumer purchase intentions in supermarkets [66].

\section{Managerial Implications}

Based on the research results, managerial implications can be recommended according to the functional management approach. According to Munandar et al. (2014), management functions consist of planning, organizing, leadership, and supervision [67].

Improvements need to be made in terms of planning to improve the image of Taichan's Satay in the form of a good impression in the eyes of consumers. Besides, it needs improvement planning to maintain and improve product-price-personal quality of consumers. In this case, the business that can be done is to maintain and improve the image of Taichan's Satay making a good impression in the eyes of consumers to improve the situation and feelings of consumers so that they feel happy when buying Taichan's Satay, by maintaining and improving product-prices-personal quality of Taichan's Satay, especially on the specific aroma of Taichan's Satay which arouse the taste and deliciousness of the Taichan's Satay and sambal which indicates that the quality of Taichan's Satay is good, as well as maintaining and improving services for consumers especially in terms of fast and responsive responses.

The organizing process includes determining the tasks, a person in charge, how the tasks are grouped, who reports to whom, and at what level decisions must be taken. To maintain product quality, prices and personal, key employees or talented employees in this case who are experts in making Taichan's Satay and sambal need to focus on their expertise and not concurrently with other jobs even during peak times of consumer visits. Clear division of work is needed from who does the service of recording the menu ordered, making and burning satay, renderer, recipient of the payment, etc., so 
that consumers can be served optimally to maintain a good impression in the eyes of consumers and maintain customer loyalty.

The leadership process includes directing, motivating all parties involved and solving conflicts that might occur. Although the Taichan's Satay business is, on average, a micro-business, a small business, to a medium-sized business, the owner or manager must be able to check the quality of the product, price and personal, so that the owner or manager must understand the quality of the product, price and personal as well. The owner or manager must be able to build good communication, accept suggestions, and criticisms from various parties for the sake of the progress of his business which according to the dominant consumer has been satisfied after consuming. The owner or manager must give an example and an impression to employees to always act professionally and be able to maintain the good name of the place of business so that it has a good image in the eyes of consumers because most consumers will recommend or suggest to others to buy Taichan's Satay at the place that they already visited.

The control process includes monitoring, comparing and improving work. In this case, raw materials need to implement good inventory management to ensure the availability of raw materials and maintained quality, considering that some raw materials have fluctuating prices that tend to be high, such as beef and chili, especially on weekends (Saturday - Sunday) which is the day most dominant consumers buy Taichan's Satay. Key employees or talented employees, in this case, especially the maker of Taichan's Satay and sambal, according to talent management need special attention both in providing training to improve their abilities, giving higher salaries or incentives if they exceed certain targets so that they feel comfortable and at ease at work resulting in Taichan's Satay which is always of high quality.

\section{Conclusion}

Based on the results of the study of the characteristics of consumers with planned purchases who buy Taichan's Satay the majority of unmarried women aged around 21-25 years and live in Bogor City. Educational status is a high school/vocational/equivalent graduate with the work of a student or college student. The average income per month of consumers with planned purchases who buy this Satay, which is less than Rp1.000.000 - Rp2.000.000. Their average monthly expenditure for buying Taichan's Satay is Rp50.001 Rp100.000. Consumers with planned purchases buying Taichan's Satay mostly have a culinary hobby.

By using the TPB approach, it is found that the factors influencing planned buying behavior (Z1) on the case of Taichan's Satay consumers in 
Bogor City are product-price-personal quality (X1) and prestige (X3) variables. Product-price-personal quality has a strong effect because it influence directly and indirectly (via intervening variable of subjective norm (Y2) and perceived behavior control (Y3)) toward the planned buying behavior. Meanwhile prestige (X3) influence only indirectly toward planned buying behavior (Z1) via intervening variable of subjective norm (Y2), and therefore the effect is not as strong as the product-price-personal quality.

In another case, although all of independent variables influence attitude believe (Y1), however they don't affect purchasing behavior, because attitude believe do not affect purchasing behavior. It is meant that the operational excellent (X2) has no effect at all toward planed purchasing behavior.

\section{Recommendation}

For institutions that are concerned with SMES's restaurant and foodstreet, they need to help in terms of expansion in product quality, price and personal, because these determinants are greatly influencing consumer planned purchase intentions directly and indirectly. Therefore, the government needs to improve by providing marketing training related to improving product quality, pricing strategies, and customer service. In addition, business actors must also pay attention to the quality of their products and provide adequate services and attractive price offers. Another thing that needs to be considered in order to compete is to build organizations among SME business actors so that they can work together in terms of distribution, prices and services.

Another determinant to be considered in relation to the prestige is enhancing the brand of restaurant or food-street. Ministry of SMEs must improve the quality of small food restaurant and food-street in order to increase the quality of prestige.

For researchers, it is necessary to develop other variables that affect business success in a food service environment, such as the online sales process, the delivery process which has now become a necessity.

\section{Acknowledgement}

I would like to express my special thanks of gratitude to my Department of Management FEM-IPB University who gave me the golden opportunity to do this wonderful project on the topic (Important Factors Influencing Consumers Planned Purchase Behavior of SMEs Foodservices Business: Case Study Taichan's Satay), which also helped me in supporting the research facilities. I am really thankful to them.

\section{Orchid}


My orcid number is 0000-0002-1500-5758; https://orcid.org/orcid search/search?searchQuery=jono\%20munandar

\section{References}

[1] C. H. Lovelock and J. Wirtz, "Services Marketing - People, Technology, Strategy," in Harvard Business Review, 2010.

[2] F. Jono M. Munandar, "ANALISIS FAKTOR YANG MEMPENGARUHI PREFERENSI KONSUMEN PRODUK AIR MINUM DALAM KEMASAN DI BOGOR," J. Agroindustrial Technol., 2004.

[3] P. J. Peter and J. C. Olson, Perilaku Konsumen dan Strategi Pemasaran. 2013.

[4] A. . Hardyasar, J. R. Mandei, and J. N. K. Dumais, "Tingkat Kepuasan Konsumen Restoran Pondok Hijau Kota Manado," Agri-Sosioekonomi, vol. 13, no. 2A, p. 157, 2017, doi: 10.35791/agrsosek.13.2a.2017.16963.

[5] J. F. Engel, R. D. Blackwell, and P. W. Miniard, "Perilaku Konsumen, Jilid 2," Jakarta Bin. Aksara, 2001.

[6] Badan Pusat Statistik Kota Bogor, "Laju Pertumbuhan Produk Domestik Regional Bruto Kota Bogor Atas Dasar Harga Konstan 2010 Menurut Lapangan Usaha (Persen), Tahun 2011 - 2016 [Internet]," 2017.

[7] Badan Pusat Statistik, SENSUS EKONOMI 2006 Evaluasi Terhadap Kriteria UMK-UMB Hasil SE06-SS. 2006.

[8] Badan Pusat Statistik Kota Bogor, "PDRB Per Kapita di Kota Bogor 2011-2017 [internet]. [accessed on 2020 Jul 24]," 2018.

[9] "Consumer attitudes and behavior: the theory of planned behavior applied to food consumption decisions," Ital. Rev. Agric. Econ., 2015, doi: 10.13128/REA-18003.

[10] Jogiyanto, Sistem Informasi Keprilakuan. Yogyakarta: Andi, 2008.

[11] S. E. Zemore and I. Ajzen, "Predicting substance abuse treatment completion using a new scale based on the theory of planned behavior," J. Subst. Abuse Treat., 2014, doi: 10.1016/j.jsat.2013.06.011.

[12] P. Kotler and G. Armstrong, Principles of Marketing 16th ed. Essex: Pearson, 2016.

[13] R. Fraser, I. Ajzen, K. Johnson, J. Hebert, and F. Chan, "Understanding employers' hiring intention in relation to qualified workers with disabilities," Journal of Vocational Rehabilitation. 2011, doi: 10.3233/JVR-2011-0548.

[14] I. Ajzen, Attitudes, Personality and Behavior (Second Edition). 2005.

[15] J. Mowen and M. Minor, Perilaku Konsumen Jilid 1. Jakarta: Erlangga, 2002 . 
[16] D. I. Hawkins and D. L. Mothersbaugh, "Consumer Behaviour Audit," in Consumer Behaviour: Building Marketing Strategy, 2013.

[17] U. Sumarwan, "Perilaku Konsumen: Teori dan penerapannya dalam Pemasaran," Ghalia Indones. Jakarta, 2003.

[18] Ujang Sumarwan, "Perilaku Konsumen Teori dan Penerapannya dalam Pemasaran, Ghalia Indonesia. Bogor," perilaku Konsum. Teor. dan penerapannya dalam Pemasar., 2011.

[19] J. M. C Lovelock, J Wirtz, Pemasaran Jasa Manusia, Teknologi, Strategi Perspektif Indonesia Jilid 1. Jakarta: Erlangga, 2011.

[20] J. Supranto and N. Limakrisna, Perilaku Konsumen dan Strategi Pemasaran untuk Memenangkan Persaingan Bisnis. Jakarta: Mitra Wacana Media, 2007.

[21] P. Kotler and G. Armstrong, Capitulo 12: Canales de marketing: transferencia de valor para el cliente. 2013.

[22] I. Fadhilah, "Analisis faktor-faktor yang memengaruhi keputusan pembelian maranggi satay di Kota Bogor [skripsi]," 2017.

[23] P. Kotler and K. L. Keller, "Marketing management (13th ed.)," in Prentice Hall., 2009.

[24] G. Joel, J. D. D. Massie, and J. L. Sepang, "PENGARUH MOTIVASI, PERSEPSI HARGA, DAN KUALITAS PRODUK TERHADAP MINAT BELI KONSUMEN SEPEDA MOTOR MATIC MEREK YAMAHA MIO DI KOTA MANADO," J. EMBA J. Ris. Ekon. Manajemen, Bisnis dan Akunt., 2017.

[25] A. I. Waluya, M. A. Iqbal, and R. Indradewa, "How product quality, brand image, and customer satisfaction affect the purchase decisions of Indonesian automotive customers," Int. J. Serv. Econ. Manag., 2019, doi: 10.1504/IJSEM.2019.100944.

[26] F. Quoquab, S. Pahlevan, J. Mohammad, and R. Thurasamy, "Factors affecting consumers' intention to purchase counterfeit product: Empirical study in the Malaysian market," Asia Pacific J. Mark. Logist., 2017, doi: 10.1108/APJML-09-2016-0169.

[27] I. Ajzen, "The theory of planned behavior," Organ. Behav. Hum. Decis. Process., 1991, doi: 10.1016/0749-5978(91)90020-T.

[28] B. L. Alford and A. Biswas, "The effects of discount level, price consciousness and sale proneness on consumers' price perception and behavioral intention," J. Bus. Res., 2002, doi: 10.1016/S01482963(00)00214-9.

[29] S. K. Mangla, S. Kusi-Sarpong, S. Luthra, C. Bai, S. K. Jakhar, and S. A. Khan, "Operational excellence for improving sustainable supply chain performance," Resources, Conservation and Recycling. 2020, doi: 
10.1016/j.resconrec.2020.105025.

[30] A. B. dan I. A. K. Mirza Fahmi*, "Agrisep Vol (14) No. 1, 201328 ANALISIS STRATEGI PEMASARAN KOPI ARABIKA 'BERGENDAAL KOFFIE' DI KABUPATEN BENER MERIAH,' Agrisep, 2013.

[31] M. W. Geddie, "Consumer Behavior in Travel and Tourism," Int. J. Hosp. Manag., 2001, doi: 10.1016/s0278-4319(01)00005-6.

[32] H. Han and Y. Kim, "An investigation of green hotel customers' decision formation: Developing an extended model of the theory of planned behavior," Int. J. Hosp. Manag., vol. 29, no. 4, pp. 659-668, 2010, doi: 10.1016/j.ijhm.2010.01.001.

[33] D. Kamajaya and N. Seminari, "PERAN LINGKUNGAN SOSIAL, EKUITAS MEREK DAN GENGSI TERHADAP NIAT BELI KONSUMEN," None, 2016.

[34] J. R. Hanaysha and R. J. Pech, "Brand prestige and the mediating role of word of mouth in the fast food industry," Glob. Bus. Rev., 2018, doi: 10.1177/0972150918794736.

[35] B. Dubois and S. Czellar, "Prestige Brands or Luxury Brands? An Exploratory Inquire on Consumer Perceptions," Eur. Mark. Acad., 2002.

[36] A. O'Cass and H. Frost, "Status brands: Examining the effects of nonproduct-related brand associations on status and conspicuous consumption," J. Prod. Brand Manag., 2002, doi: 10.1108/10610420210423455.

[37] R. Hussein and S. Hassan, "Antecedents of Global Brand Purchase Likelihood: Exploring the Mediating Effect of Quality, Prestige and Familiarity," J. Int. Consum. Mark., 2018, doi: 10.1080/08961530.2018.1455549.

[38] V. Bhardwaj, A. Kumar, and Y. K. Kim, "Brand analyses of U.S. global and local brands in India: The case of Levi's," J. Glob. Mark., 2010, doi: $10.1080 / 08911760903442226$.

[39] J. B. Steenkamp, "How global brands create firm value: The 4V model," Int. Mark. Rev., 2014, doi: 10.1108/IMR-10-2013-0233.

[40] C. L. Hsu, C. Y. Chang, and C. Yansritakul, "Exploring purchase intention of green skincare products using the theory of planned behavior: Testing the moderating effects of country of origin and price sensitivity," J. Retail. Consum. Serv., vol. 34, no. September 2016, pp. 145-152, 2017, doi: 10.1016/j.jretconser.2016.10.006.

[41] A. Fachruddin, "Sikap Konsumen dengan pendekatan Theory of Planned Behavior dan Proses pembelian tehadap Produk Cabai Kering," Institut Pertanian Bogor, 2014. 
[42] A. Tarkiainen and S. Sundqvist, "Subjective norms, attitudes and intentions of Finnish consumers in buying organic food," Br. Food J., vol. 107, no. 11, pp. 808-822, 2005, doi: 10.1108/00070700510629760.

[43] J. Paul, A. Modi, and J. Patel, "Journal of Retailing and Consumer Services Predicting green product consumption using theory of planned behavior and reasoned action," J. Retail. Consum. Serv., vol. 29, pp. $123-$ 134, 2016, doi: 10.1016/j.jretconser.2015.11.006.

[44] A. Haro, "Understanding TPB model, availability, and information on consumer purchase intention for halal food," Int. J. Bus. Commer., vol. 5, no. 8, pp. 47-56, 2016, [Online]. Available: www.ijbcnet.comwww.ijbcnet.com.

[45] Sunyoto, Praktik Riset Perilaku Konsumen. Yogyakarta: Caps, 2014.

[46] T. Suryani, "Perilaku Konsumen di Era Internet: Implikasinya pada Strategi Pemasaran," in Perilaku Konsumen di Era Internet: Implikasinya pada Strategi Pemasaran, 2013.

[47] V. W. Sujarweni, Metodelogi Penelitian: Bisnis \& Ekonomi. 2015.

[48] "Kajian Perilaku Konsumen terhadap Strategi Pemasaran Teh Herbal di Kota Bogor," Manaj. IKM J. Manaj. Pengemb. Ind. Kecil Menengah, 2011, doi: 10.29244/mikm.6.2.85-93.

[49] W. Abdillah and H. Jogiyanto, "Partial Least Square (PLS) Alternatif Structural Equation Modeling (SEM) dalam Penelitian Bisnis," in book, 2015.

[50] J. F. Hair, J. J. Risher, M. Sarstedt, and C. M. Ringle, "The Results of PLS-SEM Article information," Eur. Bus. Rev., vol. 31, no. 1, pp. 2-24, 2018

[51] C. M. Ringle and M. Sarstedt, "Gain more insight from your PLS-SEM results," Ind. Manag. Data Syst., vol. 116, no. 9, pp. 1865-1886, 2016, doi: 10.1108/imds-10-2015-0449.

[52] M. Hair, J. F., Hult, G. T. M., Ringle, C. M., \& Sarstedt, “A Primer on Partial Least Squares Structural Equation Modeling (PLS-SEM). Thousand Oaks," Sage, 2013.

[53] C. L. Wang and Z. X. Chen, "Consumer ethnocentrism and willingness to buy domestic products in a developing country setting: Testing moderating effects," J. Consum. Mark., 2004, doi: 10.1108/07363760410558663.

[54] A. Kirmani and H. Baumgartner, "Reference Points Used In Quality And Value Judgements," vol. 4, pp. 299-310, 2000.

[55] A. Shaouf, K. Lü, and X. Li, "The effect of web advertising visual design on online purchase intention: An examination across gender," Comput. Human Behav., vol. 60, pp. 622-634, 2016, doi: 


\subsection{6/j.chb.2016.02.090.}

[56] D. Iskandar, R. Nurmalina, and E. Riani, "THE EFFECT OF SERVICE , PRODUCT QUALITY , AND PERCEIVED VALUE ON CUSTOMER PURCHASE INTENTION AND SATISFACTION," vol. 1, no. 2, pp. 51-62, 2015.

[57] B. A. Saleem, A. Ghafar, M. Ibrahim, M. Yousuf, and N. Ahmed, "Product Perceived Quality and Purchase Intention withConsumer Satisfaction," Glob. J. Manag. Bus. Res. E Mark., vol. 15, no. 1, pp. p2128, 2015, [Online]. Available: https://globaljournals.org/GJMBR_Volume15/3-Product-PerceivedQuality.pdf.

[58] A. Ali, G. Xiaoling, M. Sherwani, and A. Ali, "Antecedents of consumers' Halal brand purchase intention: an integrated approach," Manag. Decis., vol. 56, no. 4, pp. 715-735, 2018, doi: 10.1108/MD-112016-0785.

[59] J. Hwang and H. Han, "A Model of Brand Prestige Formation in the Casino Industry," J. Travel Tour. Mark., vol. 33, no. 8, pp. 1106-1123, 2016, doi: $10.1080 / 10548408.2015 .1084977$.

[60] G. C. L. Chien, I. Y. Yen, and P. Q. Hoang, "Combination of Theory of Planned Behavior and Motivation: An Exploratory Study of Potential Beach-based Resorts in Vietnam," Asia Pacific J. Tour. Res., vol. 17, no. 5, pp. 489-508, 2012, doi: 10.1080/10941665.2011.627352.

[61] R. Hussain and M. Ali, "Effect of Store Atmosphere on Consumer Purchase Intention," vol. 7, no. 2, pp. 35-43, 2015, doi: 10.5539/ijms.v7n2p35.

[62] E. Triandewi and F. Tjiptono, "Consumer Intention to Buy Original Brands versus Counterfeits," vol. 5, no. 2, pp. 23-32, 2013, doi: 10.5539/ijms.v5n2p23.

[63] H. Khanifar, Z. Molavi, G. R. Jandaghi, and M. J. M. Niya, "Factors influencing the intendancy of e-banking: An integration of TAM \& TPB with eservice quality," J. Appl. Sci. Res., vol. 8, no. 3, pp. 1842-1852, 2012.

[64] A. R. Rostami, C. Valmohammadi, and J. Yousefpoor, "The relationship between customer satisfaction and customer relationship management system; a case study of ghavamin bank," Ind. Commer. Train., vol. 46, no. 4, pp. 220-227, 2014, doi: 10.1108/ICT-10-2013-0067.

[65] A. Banat and H. Wandebori, "Store design and store atmosphere effect on customer sales per visit economics," 2012.

[66] E. A. de M. Watanabe, C. V. Torres, and S. Alfinito, "The impact of culture, evaluation of store image and satisfaction on purchase intention 
at supermarkets," Rev. Gestão, vol. 26, no. 3, pp. 256-273, 2019, doi: 10.1108/rege-12-2017-0009.

[67] J. M. Munandar, L. Kartika, Y. Permanasari, R. D. Indrawan, S. M. Andrianto, and E. Siregar, Pengantar Manajemen Panduan Komprehensif Pengelolaan Organisasi. Bogor (ID): IPB Press, 2014.

\section{Appendix 1. Factor loading}

\begin{tabular}{cclc}
\hline $\begin{array}{c}\text { Factor } \\
\text { number }\end{array}$ & $\begin{array}{c}\text { New factor } \\
\text { name }\end{array}$ & \multicolumn{1}{c}{ Indicators } & $\begin{array}{c}\text { Factor } \\
\text { loadings }\end{array}$ \\
\hline X1 & Product & Deliciousness product flavor & 0.839 \\
& quality, price & Experience of buying a similar product & 0.862 \\
and personal & Re-buying product because of its quality & 0.735 \\
& & and deliciousness & \\
& & Fulfill the needs & 0.764 \\
& & Beliefs about product quality & 0.798 \\
& & Guaranteed product quality & 0.847 \\
X2 & Operational & Employee hospitality & 0.710 \\
& excellence & Sase of ordering & 0.773 \\
& & Fast response service & 0.835 \\
& & Quite long operational duration & 0.881 \\
X3 & Prestige & A good visitor circulation system & 0.887 \\
Y1 & Attitude & The power of trust 1 & 0.756 \\
& & Evaluation of results 1 & 0.771 \\
Y2 & Subjective & Strength of normative belief 1 & 1.000 \\
& norms & Motivation to obey 1 & 0.922 \\
& & Motivation to obey 3 & 0.904 \\
Y3 & Perceived & Power of confidence control 1 & 0.840 \\
& behavior & Power of confidence control 2 & 0.883 \\
& control & Power of confidence control 3 & 0.860 \\
& Purchase & Purchase intention 1 & 0.786 \\
& intention & Purchase intention 2 & 0.815 \\
& & 0.753 \\
& & 0.880 \\
& & 0.768 \\
\hline
\end{tabular}

Source: Data processed by PLS-SEM (2020)

\section{Appendix 2. $Q^{2}$ value}




\begin{tabular}{llll}
\hline & SSO & SSE & $\begin{array}{l}\mathrm{Q}^{2}(=1- \\
\text { SSE } / \text { SSO })\end{array}$ \\
\hline X1 & $1,920.000$ & $1,920.00$ & \\
X2 & $1,200.000$ & 0 & \\
& & $1,200.00$ & \\
X3 & 0 & \\
Y1 & 240.000 & 240.000 & \\
Y2 & 480.000 & 417.657 & 0.130 \\
Y3 & 720.000 & 650.952 & 0.096 \\
Z1 & 720.000 & 658.229 & 0.086 \\
\hline
\end{tabular}

Source: Data processed by PLS-SEM (2020) 